\title{
Pengaruh Rasio Kesehatan Bank terhadap Return on Assets pada Bank Umum Syariah di Indonesia
}

\author{
Heidy Paramitha Devi ${ }^{1 *}$ \\ Universitas PGRI Madiun, Indonesia \\ heidypd88@gmail.com
}

*Corresponding Author

Submitted: August 8, 2020

Accepted: October 16, 2020

Published: February 1, 2020

\begin{abstract}
Banking financial performance is reflected in their financial reports. Assessment of bank performance can be measured through financial ratio analysis approaches, one of which is the ratio of the bank's ability to generate profits or ROA. In generating good profits, a bank must be said to be healthy, the bank's health ratio which can describe the bank's health condition includes the level of capital adequacy, liquidity ratios and bank operating expense ratios. The aims of the research are to find out and analyze the influence of the level of bank health ratio on financial performance of Syariah Public Banks. The population are Bank Umum Syariah (BUS) in Indonesia which is registered in Bank Indonesia directory period 2016- 2020 that is 14 Bank Syariah. This study combined of a research object and one time dimension, measurement by data analysis tools eviews 8 , the test model chosen is the Fixed Effect Model - Least Square Dummy Variable. F test results showed that six variables simultaneously affect the amount of lending with the value of Prob (F-statistic) 0.000000. Hypothesis test results showed that CAR and NPF ratios has no influence to ROA, while FDR has a positive significant influence to ROA and BOPO ratio has negative influence to ROA.
\end{abstract}

Keywords: Bank Umum Syariah (BUS), Financial Ratios

\section{PENDAHULUAN}

Kinerja intermediasi perbankan memiliki pengaruh yang besar terhadap roda perekonomian dunia, yang mana sumber utama dananya berasal dari masyarakat sehingga secara moral mereka harus menyalurkannya kembali kepada masyarakat dalam bentuk kredit. Demikian halnya dengan Indonesia, bank umum mempunyai peran penting terhadap perekonomian karena lebih dari 95\% Dana Pihak Ketiga (DPK) perbankan nasional yang meliputi Bank Umum (CommercialBank), Bank Syariah (Sharia Bank), dan Bank Perkreditan Rakyat (Rural Bank) berada di Bank Umum.

Bank Syariah merupakan bank yang aktivitasnya meninggalkan riba (Muhammad, 2013). Di dalam UU no. 21 tahun 2008 yang dimaksud riba adalah penambahan pendapatan secara tidak sah (bathil) antara lain dalam transaksi pertukaran barang sejenis yang tidak sama kualitas, kuantitas, dan waktu penyerahan ( $f a d h l)$, atau dalam transaksi pinjammeminjam yang mempersyaratkan Nasabah Penerima Fasilitas mengembalikan dana yang diterima melebihi pokok pinjaman karena berjalanya waktu. Dilihat dari definisi riba, bunga yang dibebankan bank konvensional terhadap nasabahnya termasuk dalam unsur riba.

Kegiatan penyaluran kredit merupakan aktivitas utama pebankan syariah, dengan 
sistem bagi hasil (sharing profit). Meskipun demikian dari aktivitas tersebut juga dapat menimbulkan resiko besar, diantaranya resiko gagal bayar/kredit macet yang berujung pada menipisnya modal dan pendapatan, hilangnya kepercayaan investor yang berdampak pada turunnya aset perusahaan. Oleh karena itu penyaluran kredit harus diiringi dengan manajemen risiko yang ketat. Para pelaku bisnis, terutama investor perlu mengetahui kondisi kesehatan maupun kinerja perusahaan saat ini untuk memprediksi kondisi perusahaan tersebut di masa yang akan datang melalui analisis laporan keuangan. Model umum yang digunakan dalam melakukan analisis laporan keuangan adalah dalam bentuk rasio-rasio keuangan.

Otoritas moneter di Indonesia telah menetapkan Rasio Permodalan (Capital), Kualitas Aktiva Produktif (Assets Quality), Manajemen (Management), Pendapatan (Earning), Likuiditas (Liquidity) sebagai tata cara penilaian tingkat kesehatan bank umum, seperti tertuang dalam Surat Keputusan Direksi BI No. 26/23/KEP/DIR tanggal 29 Mei 1993, BI No. 26/5/BPPP, tanggal 29 Mei 1993 yang telah diperbaharui melalui Surat Keputusan Direksi Bank Indonesia No. 30/11/KEP/DIR tanggal 30 April 1997, Surat Edaran Bank Indonesia No. 30/2/UPPB tanggal 30 April 1997, Keputusan Direksi Bank Indonesia No.30/277/KEP/DIR tanggal 19 Maret 1998. Aspek permodalan yang diproksikan kedalam rasio CAR, aspek likuiditas diproksikan kedalam rasio NPF dan FDR, aspek asset quality diproksikan kedalam rasio ROA, aspek management diproksikan kedalam rasio BOPO.

Ukuran profitabilitas yang digunakan adalah Return On Asset (ROA) pada industri perbankan. Return On Asset (ROA) adalah rasio yang menggambarkan kemampuan bank dalam mengelola dana yang diinvestasikan dalam keseluruhan aktiva yang menghasilkan keuntungan (Muhammad, 2013). Non Performing Financing (NPF) merupakan rasio keuangan yang menunjukkan risiko pembiayaan yang dihadapi bank akibat pemberian pembiayaan dan investasi dana bank pada portofolio yang berbeda. Risiko pembiayaan ini dapat terjadi akibat kegagalan atau ketidakmampuan nasabah dalam mengembalikan jumlah pinjaman yang diterima dari bank beserta bagi hasilnya sesuai dengan jangka waktu yang telah dijadwalkan (Mudrajad, 2002). NPF dibank syariah berdasarkan data OJK telah melampaui batas maksimum yaitu 5\% dengan idealnya dibawah 5\%. Non Performing Financing (NPF) dalam penelitian (Kolapo, 2012) menunjukkan adanya pengaruh negatif terhadap Profitabilitas. Hal ini bertentangan dengan hasil penelitian yang dilakukan (Ponttie, 2007) yang menunjukkan adanya pengaruh yang positif antara Non Performing Financing (NPF) terhadap Return On Asset (ROA). Dengan adanya research gap dari penelitian sebelumnya, maka perlu dilakukan penelitian lanjutan pengaruh Non Performing Financing (NPF) terhadap Return On Asset (ROA).

Financing to Deposit Ratio (FDR) yang analog dengan Loan to Deposit Ratio pada bank konvensional adalah perbandingan antara pembiayaan yang diberikan oleh bank dengan dana pihak ketiga yang berhasil dihimpun oleh bank. Semakin rendah FDR menunjukkan kurangnya efektifitas bank dalam menyalurkan kredit. Jika rasio FDR atau LDR untuk kebanyakan BUS berada pada standar dibawah $100 \%$ yang ditetapkan oleh Bank Indonesia. Maka laba yang diperoleh oleh bank tersebut akan meningkat (dengan asumsi bank tersebut mampu menyalurkan kreditnya dengan efektif). Dengan meningkatnya laba, maka Return On Asset (ROA) juga akan meningkat, karena laba merupakan komponen yang membentuk Return On Asset (ROA). Financing to Deposit Ratio (FDR) yang diteliti oleh (Widowati, 2015) menunjukkan bahwa Financing to Deposit Ratio (FDR) berpengaruh positif terhadap Return On Asset (ROA). Sedangkan hasil penelitian yang dilakukan oleh (Werdaningtyas, 2002) menunjukkan adanya pengaruh 
negatif antara variabel Financing to Deposit Ratio (FDR) terhadap Return On Asset (ROA). Dengan adanya research gap dari penelitian sebelumnya, maka perlu dilakukan penelitian lanjutan pengaruh Financing to Deposit Ratio (FDR) terhadap Return On Asset (ROA).

Besar CAR sudah ditetapkan sebesar $8 \%$ oleh Bank of International Settlement (BIS) dan di Indonesia sudah diatur dalam Peraturan Bank Indonesia Nomor 6/10/PBI/2004 tentang Sistem Penilaian Tingkat Kesehatan Bank Umum. Perhitungan CAR dilakukan dengan cara membagi modal terhadap Aktiva Tertimbang Menurut Risiko (ATMR) jadi semakin besar CAR maka akan semakin sehat juga bank tersebut. Menurut (Puspitasari, 2009) CAR berpengaruh positif signifikan terhadap ROA, namun penelitian yang dilakukan oleh (Buchory, 2015) dan (Wibowo, 2013) menyatakan bahwa secara tidak signifikan CAR berpengaruh negatif terhadap ROA

Rasio Biaya Operasional terhadap Pendapatan Operasional (BOPO) digunakan untuk mengukur tingkat efisiensi dan kemampuan bank dalam melakukan kegiatan operasinya Bank Indonesia meminta menurunkan BOPO menjadi 80\% karena semakin rendah tingkat rasio BOPO berarti semakin baik kinerja manajemen bank tersebut, karena lebih efisien dalam menggunakan sumber daya yang ada di perusahaan. Dari hasil penelitian (Pahlevie, 2009) BOPO tidak berpengaruh terhadap Return On Asset (ROA). Penelitian (Muliawati, 2015) Biaya Operasional terhadap Pendapatan Operasional berpengaruh positif terhadap Return On Asset (ROA) sedangkan (Abusharbeh, 2014) menyatakan berpengaruh negatif antara variabel Biaya Operasional terhadap Pendapatan Operasional terhadap Return On Asset (ROA). Dengan adanya research gap dari penelitian sebelumnya, maka perlu dilakukan penelitian lanjutan pengaruh Biaya Operasional terhadap Pendapatan Operasional (BOPO) terhadap Return On Asset (ROA)

Tabel 1.1 Rasio Keuangan pada Bank Umum Syariah

\begin{tabular}{|l|l|l|l|l|l|}
\hline Th & $\begin{array}{l}\text { ROA } \\
(\%)\end{array}$ & $\begin{array}{l}\text { NPF } \\
(\%)\end{array}$ & $\begin{array}{l}\text { CAR } \\
(\%)\end{array}$ & $\begin{array}{l}\text { FDR } \\
(\%)\end{array}$ & $\begin{array}{l}\text { BOPO } \\
(\%)\end{array}$ \\
\hline 2016 & 0.63 & 4.42 & 16,63 & 85,99 & 96,22 \\
\hline 2017 & 0.63 & 4.76 & 17,91 & 79,61 & 94,91 \\
\hline 2018 & 1.28 & 3.26 & 20,39 & 78,53 & 89,18 \\
\hline 2019 & 1.73 & 3.23 & 20,59 & 77,91 & 84,45 \\
\hline 2020 & 1.85 & 3.38 & 20,47 & 78,69 & 84,60 \\
\hline
\end{tabular}

Sumber: Data Bank Indonesia (Statistik Perbankan Indonesia dan Statistik Ekonomi Moneter Indonesia, diolah 2020.

Pergerakan aset yang diproksikan oleh rasio ROA mengalami peningkatan, sedangkan FDR mengalami penurunan sampai dengan tahun 2019. Hal tersebut betolak belakang dengan teori yang menyatakan bahwa FDR memiliki pengaruh positif terhadap ROA. Demikian halnya dengan proporsi rasio CAR mengalami penurunan di tahun 2020. Selanjutnta rasio NPF mengalami kenaikan searah dengan dengan naiknya ROA, hal ini bertentangan dengan teori yang menyatakan bahwa NPF berpengaruh negatif terhadap ROA, demikian juga halnya dengan rasio BOPO.

\section{Pengaruh CAR terhadap ROA}

\section{STUDI LITERATUR}

CAR merupakan rasio yang menunjukkan kemampuan bank dalam menyediakan dana untuk keperluan pengembangan usaha serta menampung resiko kerugian dana. Nilai 
CAR yang tinggi berbanding lurus dengan sumber daya finansial yang dapat digunakan untuk keperluan pengembangan usaha dan mengantisipasi potensi kerugian yang diakibatkan oleh penyaluran kredit. Dengan CAR diatas 20\%, perbankan bisa memacu pertumbuhan kredit hingga 20- 25\% setahun (Wibowo, 2013) Kiat yang banyak ditempuh oleh bank untuk memperkuat CAR dalam rangka menggenjot ekspansi kredit pada tahun berikutnya adalah dengan penerbitan obligasi subordinasi (subdebt) dan right issue. Maka dapat disimpulkan bahwa semakin tinggi CAR, profitabilitas (ROA) suatu bank akan semakin tinggi pula. Hal ini menandakan bahwa hubungan antara CAR searah dengan profitabilitas (ROA) atau positif. Pengaruh antara CAR terhadap profitabilitas (ROA) dapat didasarkan pada hasil penelitian yang telah ada. Hasil penelitian yang dilakukan oleh (Puspitasari, 2009), (Pramudhito, 2014), dan (Windriya, 2014) menemukan bahwa CAR berpengaruh positif terhadap profitabilitas (ROA) bank syariah. Menurut (Puspitasari, 2009), CAR berpengaruh positif signifikan terhadap ROA. Penelitian yang dilakukan oleh (Bateni, 2014) mengenai pengaruh Capital Adequacy Ratio (CAR) terhadap Return On Asset (ROA) menunjukkan hasil yang positif.

H 1: CAR berpengaruh positif terhadap ROA pada BUS

\section{Pengaruh NPF terhadap ROA}

NPF merupakan rasio yang dipergunakan untuk mengukur kemampuan bank dalam meng-cover risiko kegagalan pengembalian kredit oleh debitur (Darmawan, 2004). Semakin kecil NPF semakin kecil pula risiko kredit yang ditanggung pihak bank. Sebaliknya apabila semakin besar NPF suatu bank akan berdampak pada menurunnya profitabilitas (ROA). Hal ini disebabkan oleh meningkatnya biaya yang dikeluarkan bank yaitu biaya pencadangan aktiva produktif yang dibutuhkan menjadi lebih tinggi (Rivai, 2010). Dengan demikian dapat disimpulkan bahwa NPF berpengaruh negatif terhadap profitabilitas bank syariah. Hal ini sesuai dengan penelitian yang dilakukan oleh (Fahmy, 2013), (Adyani, 2011) dan (Windriya, 2014) yang menemukan bahwa NPF berpengaruh negatif terhadap profitabilitas bank syariah. Padahal besaran modal sangat mempengaruhi besarnya ekspansi kredit. Penelitian (Adyani, 2011) menunjukkan hasil bahwa NPF berpengaruh negatif signifikan terhadap ROA.

H 2: NPF berpengaruh negatif terhadap ROA pada BUS

\section{Pengaruh FDR terhadap ROA}

Apabila suatu bank memiliki rasio FDR sebesar 75\% (dibawah standar ideal) maka dapat diartikan bank hanya menyalurkan $75 \%$ dari seluruh dana yang dihimpun. Di sisi lain apabila rasio FDR mencapai lebih dari $100 \%$, dapat dikatakan bahwa bank melampaui batas ideal yang telah ditetapkan oleh Asbisindo. FDR dihitung dari pembiayaan dibagi dengan dana pihak ketiga, apabila dana dari pihak ketiga yang berhasil dihimpun tinggi maka penyaluran pembiayaan juga tinggi, pembiayaan tinggi dapat menghasilkan laba yang tinggi pula, sehingga akan meningkatkan profitabilitas perusahaan. Jika rasio FDR yang dimiliki oleh bank sesuai dengan batas ideal maka laba yang diperoleh bank akan meningkat (Sangia, 2012). Tetapi apabila rasio FDR rendah berarti menunjukan kurangnya efektifitas bank dalam menyalurkan pembiayaan, sehingga likuiditas bank menjadi rendah. Hal ini didukung dengan hasil penelitian dari (Puspitasari, 2009) dan (Pramudhito, 2014) yang menemukan bahwa FDR berpengaruh positif terhadap profitabilitas (ROA) bank syariah.

H 3: FDR berpengaruh positif terhadap ROA pada BUS 


\section{Pengaruh BOPO terhadap ROA}

Rasio BOPO ini mengukur kemampuan pendapan operasional dalam menutup biaya operasional, dari nilai BOPO ini dapat dilihat kondisi kinerja bank yang bersankutan. Menurut (Sangia, 2012) rasio BOPO merupakan upaya sebuah bank untuk meminimalkan risiko operasional, yang merupakan ketidakpastian dalam kegiatan usaha yang dijalankan oleh bank. Risiko operasional berasal dari kerugian dan kemungkinan terjadinya kegagalan atas jasa dan produk-produk yang ditawarkan. Apabila rasio BOPO pada suatu bank tinggi maka berarti bahwa biaya yang dikeluarkan bank untuk operasional lebih besar daripada pendapatan operasional yang masuk ke bank. Apabila pendapatan operasional bank kecil maka tingkat profitabilitas (ROA) bank menjadi rendah. Hal ini menunjukan adanya hubungan yang berlawanan antara BOPO dengan tingkat profitabilitas (ROA) suatu bank yang sejalan dengan penelitian (Adyani, 2011), (Fahmy, 2013), (Wibowo, 2013), (Windriya, 2014) yang menemukan bahwa BOPO berpengaruh negatif terhadap profitabilitas bank syariah.

H 4: BOPO berpengaruh negatif terhadap ROA pada BUS

\section{METODE}

Metode analisis dalam penelitian ini menggabungkan data time series dan cross section. Data yang digunakan adalah data sekunder yang diambil dari laporan keuangan tahunan perusahaan perbankan syariah periode 2016-2020 yang tersedia dan dipublikasikan di website resmi $w w w . o j k . g o . i d$. Analisis data yang dilakukan adalah analisis data kuantitatif yang dinyatakan dengan angka-angka yang dalam perhitunganya menggunakan metode statistik yang dibantu dengan alat uji eviews 8. Pemilihan regresi dipilih melalui tahapan pengujian model dan lolos pengujian asumsi klasik. Analisis data yang digunakan dalam penelitian ini yaitu deskriptif statistik, uji Chow dan uji Hausman untuk penentuan model yang tepat, uji asumsi klasik dan pengujian kriteria statistik.

\section{Populasi dan Sampel}

Populasi adalah keseluruhan individu, kejadian atau sesuatu yang akan dijadikan obyek penelitian dan mempunyai sifat yang sama (Sekaran, 2011). Populasi dalam penelitian ini adalah Bank Umum Syariah di Indonesia pada tahun 2016-2020 dipublikasikan oleh Otoritas Jasa Keuangan yang berjumlah 14 bank.

HASIL

Tabel 3.1 Analisis Statistik Deskriptif

\begin{tabular}{|l|l|l|l|l|l|}
\hline & Mean & Median & Max & Min & Std. Dev \\
\hline $\begin{array}{l}\text { Profitabilitas } \\
\text { (ROA) }\end{array}$ & $\begin{array}{l}29575106, \\
0000\end{array}$ & $\begin{array}{l}3831220, \\
0000\end{array}$ & $\begin{array}{l}595000000, \\
0000\end{array}$ & 3368.0000 & $\begin{array}{l}79920451, \\
0000\end{array}$ \\
\hline CAR & 19,7134 & 16,8300 & 87,4900 & 8,0200 & 10,7677 \\
\hline NPF & 2,2649 & 2,0200 & 12,2800 & 0,0000 & 1,9772 \\
\hline FDR & 83,7183 & 85,0000 & 173,8000 & 43,4600 & 14,9075 \\
\hline BOPO & 83,1785 & 85,8800 & 173,8000 & 3,5700 & 19,8792 \\
\hline
\end{tabular}

Berdasarkan hasil perhitungan didapatkan bahwa nilai minimum 8,02\% dan maksimum 87,49\%. Hal ini menunjukkan bahwa CAR Bank Syariah sudah memenuhi standar yang ditetapkan Bank Indonesia, yaitu minimal 8\%. Rata-rata nilai CAR dari 
Bank Syariah adalah 19,71\%, lalu standar deviasi CAR adalah 10,76 \%. Nilai terendah tersebut dimiliki oleh Bank Bukopin pada kuartal ketiga tahun 2017. Lalu nilai tertinggi dimiliki oleh Bank Syariah Mandiri pada kuartal pertama pada tahun 2017 juga. NPF yang diperoleh menunjukkan nilai minimumnya $0,000 \%$ dan nilai maksimumnya $12,2800 \%$. Berdasarkan Standar Bank Indonesia besaran nilai NPF adalah maksimal 5\%. Hal ini menunjukkan bahwa kemampuan Bank Syariah dalam mengelola kredit bermasalah masih belum maksimal, banyak faktor yang mempengaruhi seperti: minimnya angka kecukupan modal, besarnya biaya operasional atau kondisi ekonomi global yang menyebabkan angka pengembalian kredit kurang dari batas minimal. Nilai NPF terendah dimiliki oleh BCA Syariah kuartal pertama pada tahun 2018, sedangkan nilai tertinggi pada Bank Muamalat di kuartal ketiga tahun 2018. BOPO yang diperoleh menunjukkan nilai minimumnya adalah 3,57\% dan nilai maksimumnya adalah $173,800 \%$. Berdasarkan standar Bank Indonesia besarnya nilai BOPO yang normal adalah 94\% - 96\%. Hal ini berarti Bank Syariah kurang efisien dalam mengelola biaya operasionalnya. Lalu untuk rata- ratanya adalah $83,1785 \%$ dan standar deviasinya adalah $19,879 \%$. Nilai BOPO terendah dimiliki oleh Bank Syariah Mandiri kuartal kedua pada tahun 2017, lalu nilai tertinggi pada Bank Mega Syariah di kuartal ketiga pada tahun 2018. FDR untuk Bank Syariah dari tahun 2016 sampai 2020 memiliki nilai terendah 43,460\% dan nilai tertinggi $173,800 \%$. Berdasarkan standar Bank Indonesia FDR yang normal adalah berada diantara $80 \%-110 \%$, lalu nilai standar yang disarankan oleh Dendawijaya adalah $85 \%-100 \%$. Dengan demikian rasio yang dimiliki oleh Bank Syariah belum memenuhi standar Bank Indonesia. Lalu untuk rata-rata yang diperoleh adalah $83,7185 \%$ sementara untuk nilai standar deviasi diperoleh $14,9075 \%$. Nilai terendah dan tertinggi terdapat pada tahun 2016. Nilai terendah ada pada kuartal pertama di Bank Victoria Syariah, lalu nilai tertinggi ada pada kuartal kedua di Bank BNI Syariah.

\section{Tabel 3.2 Uji Chow (Uji F Restricted)}

\begin{tabular}{|l|l|l|}
\hline \multicolumn{3}{|c|}{ Cross Section Fixed Effect } \\
\hline F-stat & Prob. & Keputusan \\
\hline 28,18080 & 0,000000 & Fixed Effect \\
\hline \multicolumn{3}{|c|}{ Sumber: Data diolah 2020 } \\
\hline
\end{tabular}

Hasil uji Chow dari tabel diatas menunjukkan nilai probabilitas F-statistik 0,000000 $<$ dari 0,05. Nilai F-statistik 28,18080 > dari F-tabel 2,14. Nilai tersebut menghasilkan keputusan bahwa $\mathrm{H} 0$ ditolak dan $\mathrm{H} 1$ diterima. Pada penelitian ini model Fixed Effect merupakan metode yang tepat dalam mergresi data panel. Hasil uji Chow memberikan keputusan bahwa model Fixed Effect lebih baik dan akan dilanjutkan dengan uji Hausman.

Tabel 3.3 Uji Hausman

\begin{tabular}{|l|l|l|}
\hline \multicolumn{3}{|c|}{ Cross Section Random Effect } \\
\hline Chi-Sq.Stat & Prob. & Keputusan \\
\hline 19,961016 & 0,0037 & Fixed Effect \\
\hline
\end{tabular}

Hasil uji Hausman pada tabel diatas menunjukkan Chi-Square.Stat sebesar 19,259690 signifikansi pada 0,0037. Nilai Chi-Square.Stat uji Hausman lebih besar (>) dari kritis Chi-Square dengan signifikansi 0,05 dan df 6. Nilai uji Hausman 19,259690 lebih besar (>) dari 12,5916, maka model yang dipilih adalah Fixed Effect Model. 
Tabel 3.4 Hasil Uji Heterokesdasitas dengan Uji Park

\begin{tabular}{|l|l|l|}
\hline Variabel & t-stat & Prob. \\
\hline CAR & $-1,843177$ & 0,0672 \\
\hline NPF & $-0,844648$ & 0,3996 \\
\hline FDR & 0,137543 & 0,8908 \\
\hline BOPO & 0,816230 & 0,4156 \\
\hline \multicolumn{2}{|c|}{ Sumber: Data diolah, 2020 } \\
\hline
\end{tabular}

Tabel hasil uji Park menunjukkan bahwa probabilitas semua variabel independen menunjukkan nilai yang signifikan yaitu CAR $(0,0672), \operatorname{NPF}(0,3996), \operatorname{FDR}(0,8908)$ dan BOPO $(0,4156)$ lebih besar (>) dari 0,05. Jadi dapat disimpulkan bahwa model regresi tidak mengandung adanya heteroskedasitas.

Tabel 3.5 Durbin Watson

\begin{tabular}{|l|l|}
\hline Durbin Watson Stat. & Kesimpulan \\
\hline 1,837826 & Tidak terjadi autokorelasi \\
\hline
\end{tabular}

Sumber: Data diolah, 2020

Hasil uji Durbin Watson dalam penelitian ini adalah sebesar 1,837826. Nilai statistiknya berada diantara 1,55 dan 2,46 sehingga dapat disimpulkan bahwa tidak terjadi autokorelasi.

Tabel 3.6 Hasil Uji Multikolinieritas (Correlation matrix)

\begin{tabular}{|l|l|l|l|l|}
\hline & CAR & NPF & FDR & BOPO \\
\hline CAR & 1 & 0.033 & -0.061 & 0.060 \\
\hline NPF & 0.033 & 1 & 0.020 & 0.045 \\
\hline FDR & -0.061 & 0.020 & 1 & -0.057 \\
\hline BOPO & 0.060 & 0.045 & -0.057 & 1 \\
\hline \multicolumn{5}{|c}{ Sumber: Data diolah, 2020 } \\
\hline
\end{tabular}

Berdasarkan tabel Corelation Matrix nilai masing-masing variabel independen dibawah 90\%. Jadi dapat disimpulkan bahwa tidak terjadi multikolonieritas antar variabel independen dalam model regresi penelitian ini.

Tabel 3.7 Hasil Uji Pendekatan Koutsoyiannis

\begin{tabular}{|l|l|}
\hline R-Squared (Regresi Awal) & 0,606604 \\
\hline R-Squared (Regreasi Parsial-CAR) & 0,308104 \\
\hline R-Squared (Regreasi Parsial-NPF) & 0,457949 \\
\hline R-Squared (Regreasi Parsial-FDR) & 0,511357 \\
\hline R-Squared (Regreasi Parsial-BOPO) & 0,297298 \\
\hline
\end{tabular}

Sumber: Data diolah, 2020

Tabel hasil uji pendekatan Koutsoyiannis menunjukan nilai $R^{2}$ pada regresi awal dengan empat variabel bebas yaitu 0,606604 . Nilai $R^{2}$ tersebut lebih tinggi dibanding $R^{2}$ pada regresi masing-masing variabel bebas. Hasil ini menunjukkan bahwa variabel CAR, NPF, FDR, BOPO berguna atau layak dimasukkan ke dalam model.

Tabel 3.8 Hasil Uji Fixed Effect Model

\begin{tabular}{|l|l|l|l|l|}
\hline Variabel & Coefficient & Std. Error & t-Statistik & Prob. \\
\hline C & $-2.06 \mathrm{E}+08$ & 50190925 & $-4,112168$ & 0,0001 \\
\hline
\end{tabular}


Owner: Riset \& Jurnal Akuntansi

e-ISSN : 2548-9224 |p-ISSN : 2548-7507

Volume 5 Nomor 1, Februari 2021

DOI : https://doi.org/10.33395/owner.v5i1.311

\begin{tabular}{|l|c|c|c|c|}
\hline CAR & -1192773, & 743728,7 & $-1,603774$ & 0,1108 \\
\hline NPF & 7674842, & 2534254, & $-3,028442$ & 0,0029 \\
\hline FDR & 1689390, & 354288,8 & 4,768399 & 0,0000 \\
\hline BOPO & $-214869,5$ & 424581,7 & $-0,506073$ & 0,6135 \\
\hline
\end{tabular}

Effect Specification

Cross-section fixed (dummy variables)

\begin{tabular}{|l|l|}
\hline$R$-squared & 0,606604 \\
\hline Adjusted R-squared & 0,492071 \\
\hline F-statistik & 5,296318 \\
\hline Probab (F-Statistik) & 0,000000 \\
\hline
\end{tabular}

Sumber: Data diolah, 2020. Dependent variable: ROA, predictors: (Constant), CAR, NPF, FDR, BOPO, signifikansi $5 \%$ $(*)$.

Tabel 3.9 Hasil Uji Hipotesis

\begin{tabular}{|l|l|l|l|}
\hline Hipotesis & $\begin{array}{l}- \\
/+\end{array}$ & Signifikansi & Diterima/Ditolak \\
\hline H1 : CAR berpengaruh + signifikan & - & 0,1108 & Ditolak \\
\hline H2 : NPF berpengaruh - signifikan & - & 0,0029 & Diterima* \\
\hline H3 : FDR berpengaruh + signifikan & + & 0,0000 & Diterima* \\
\hline H4 : BOPO berpengaruh - signifikan & - & 0,6135 & Ditolak \\
\hline $\begin{array}{l}\text { Sumber: Data diolah, 2020. Dependent variable: ROA, predictors: (Constant), CAR, NPF, FDR, BOPO, signifikansi 5\% } \\
(*) .\end{array}$
\end{tabular}

Dari tabel di atas menunjukkan bahwa $\mathrm{H} 2$ dan $\mathrm{H} 3$ memiliki nilai signifikansi dibawah 5\%, artinya hipotesis dapat diterima. Disisi lain $\mathrm{H} 1$ dan $\mathrm{H} 4$ memiliki nilai signifikansi diatas 5\%, artinya hipotesis tidak dapat diterima. Maka disimpulkan bahwa Capital Adequacy Ratio (CAR) dan Beban Operasional terhadap Pendapatan Operasional (BOPO) tidak ada pengaruh signifikan terhadap Return On Asset (ROA). Rasio Non Performing Financing (NPF) dan Financing to Deposit Ratio (FDR) memiliki pengaruh signifikan terhadap Return On Asset (ROA).

\section{PEMBAHASAN}

Berdasarkan hasil pengujian diketahui bahwa Uji Fixed Effect Model menunjukkan bahwa CAR tidak memiliki pengaruh secara signifikan terhadap ROA. Hasil temuan ini mendukung hasil penelitian (Widyaningrum L, 2015), (Almunawwaroh M, 2018) yang menyatakan bahwa CAR tidak berpengaruh terhadap ROA Tetapi, hasil penelitian ini berbeda dengan temuan penelitian (Mawardi, 2004), (Puspitasari, 2009), (Restiyana, 2011), (Fahmy, 2013), (Hardiyanti, 2012) yang menyatakan bahwa CAR berpengaruh positif terhadap ROA. Bila dilihat tidak berpengaruhnya CAR terhadap ROA kemungkinan karena bank-bank yang beroperasi pada tahun tersebut sangat menjaga besarnya modal yang ada atau dimiliki. Hal ini karena adanya peraturan Bank Indonesia yang mensyaratkan CAR minimal sebesar 8\% mengakibatkan bank-bank selalu berusaha menjaga agar CAR yang dimiliki sesuai dengan ketentuan. Nilai CAR ini diperoleh dari modal bank dibanding dengan ATMR. Seperti yang dikatakan oleh (Dendawijaya, 2005) bahwa contoh ATMR adalah kredit yang diberikan kepada masyarakat oleh pihak bank. Jadi semakin besar ATMR maka akan menurun nilai dari CAR dan sebaliknya semakin kecil ATMR maka akan meningkat nilai CAR. Dilain pihak, kredit yang diberikan kepada masyarakat dapat membuka kesempatan bank untuk memperoleh pendapatan dari bunga 
pinjaman yang diberikan. Dengan demikian kemungkinan lainnya CAR tidak berpengaruh terhadap ROA adalah bank belum dapat melempar kredit sesuai dengan yang diharapkan atau belum optimal.

Dari hasil perhitungan yang didapat NPF signifikan negatif, interpretasinya adalah semakin besar jumlah penyaluran kredit semakin besar besar pula angka risiko kredit tidak kembali yang artinya bahwa perusahaan dalam hal ini bank syariah tidak dapat mengelola penggunaan aktivanya untuk mendapatkan laba melainkan dialih fungsikan menutup angka kredit bermasalah, agar tetap dikatakan sehat. Hal tersebut berakibat pada menurunnya angka rasio aset. Hasil temuan ini sejalan dengan temuan (Khasanah, 2017), (Anada, 2013), (Pratiwi, 2015), (Warsa, 2016) yang menunjukkan hasil bahwa NPL memiliki pengaruh negatif dan signifikan terhadap ROA dan bersebrangan dengan hasil temuan (Almunawwaroh M, 2018).

Dari hasil perhitungan yang didapat FDR memiliki pengaruh signifikan positif terhadap ROA. Hal tersebut menunjukkan bahwa semakin besar Loan to Deposit Ratio (LDR) maka laba yang diperoleh bank (ROA) akan meningkat. Tentunya dengan syarat bank tetap mempertahankan prinsip kehati- hatian dan menekan timbulnya kredit macet. Dengan meningkatnya laba (ROA) maka kinerja keuangan bank yang bersangkutan semakin membaik atau meningkat. Hasil temuan ini mendukung hasil penelitian dari (Mahardian, 2008), (Puspitasari, 2009), dan yang menunjukkan bahwa Loan to Deposit Ratio (LDR) berpengaruh positif signifikan terhadap Return On Asset (ROA).

Dari hasil perhitungan yang didapat rasio BOPO tidak memiliki pengaruh signifikan terhadap ROA. Hal tersebut dikarenakan angka kecukupan modal yang dimiliki perbankan syariah dalam waktu amatan ada pada angka yang bagus, sehingga ketika biaya operasional tinggi tidak menurunkan jumlah aset. Hasil temuan ini didukung oleh kajian dari (Hendrayanti, 2013) berbeda dengan hasil temuan (Wibowo, 2013), (Utami, 2015) yang menyatakan bahwa BOPO memang memiliki pengaruh negatif signifikan terhadap ROA.

\section{KESIMPULAN}

Penelitian ini bertujuan untuk mendapatkan bukti empiris pengaruh rasio CAR, NPF, FDR, BOPO terhadap kinerja keuangan perbankan yang diproksikan ke dalam rasio ROA. Penelitian ini menggunakan data panel dengan bantuan alat analisis data eviews 8, model uji yang terpilih adalah Fixed Effect Model - Least Square Dummy Variable. Populasi penelitian adalah bank umum syariah yang kemudian dilakukan purposive sampling, sehingga diperoleh jumlah sampel sebanyak 70 dari tahun 2016-2020. Hasil uji f menunjukkan bahwa dari keenam variabel secara simultan mempengaruhi profitabilitas dengan nilai Prob (F-statistik) sebesar 0,000000. Hasil uji hipotesis diperoleh hasil bahwa rasio CAR dan BOPO tidak berpengaruh signifikan terhadap ROA, yang artinya bahwa $\mathrm{H} 1$ dan H4 ditolak. Rasio FDR berpengaruh positif signifikan terhadap ROA, sedangkan NPF berpengaruh negatif signifikan terhadap ROA, yang artinya bahwa $\mathrm{H} 2$ dan $\mathrm{H} 3$ diterima. Penelitian ini memiliki keterbatasan dimana dari keempat variabel dependent hanya mampu menjelaskan pengaruhnya terhadap ROA sebesar 49,20\% diperoleh dari nilai Adjusted R-Squared sebesar 0,492071

\section{Saran}

Untuk penelitian selanjutnya disarankan untuk dapat melengkapi keterbatasan dari penelitian sebagai berikut. Pada penelitian berikutnya perlu dilakukan penambahan variabel pemoderasi seperti Good Corporate Governance atau variabel kontrol seperti Ukuran Bank (size). 


\section{DAFTAR PUSTAKA}

Abusharbeh, M. T. (2014). Credit Risk and Profitability of Islamic Banks: Evidence from Indonesia. World Review of Business Research. Vol. 4. No. 3.

Adyani, L. R. (2011). Analisis Faktor-Faktor yang Mempengaruhi Profitabilitas (ROA) (pada Bank Umum Syariah yang Terdaftar di BEI periode Desember 2005 September 2010). Semarang: Fakultas Ekonomi.

Almunawwaroh M, M. R. (2018). Pengaruh CAR, NPF dan FDR terhadap Profitabilitas Bank Syariah di Indonesia. Amwaluna Vol 2 No 1, 1-17.

Anada, M. (2013). Analisis pengaruh CAR, FDR, NPF dan BOPO terhadap ROA Bank Umum Syariah (Studi Kasus padda Bank Umum Syariah di Indonesia periode 2010-2012). Sumatera Utara: UIN.

Bank, I. (2004). Surat Edaran Bank Indonesia Nomor 6/23/DPNP Mei 31. Jakarta.

Bateni, L. e. (2014). The Influential Factors on Capital Adequacy Ratio in Iranian Banks. Journal of Economic and Finance, Vol. 6, No. 11.

Buchory, H. A. (2015). Banking Profitability: How does the Credit Risk and Operational Efficiency Effect? . Journal of Business and Management Sciences, 3(4):118-123.

Darmawan, K. (2004). Analisis Rasio-Rasio Bank. Jakarta: Info Bank.

Dasih, K. (2014). Pengaruh Rasio Keuangan Terhadap Return On Asset Perbankan (Studi pada Bank Umum yang Terdaftar di Bursa Efek Indonesia Periode 2007-2013). Yogyakarta: Fakultas Ekonomi Universitas Negeri Yogyakarta.

Dendawijaya, L. (2005). Manajemen Perbankan. Jakarta: Ghalia Indonesia.

Fahmy, M. S. (2013). Pengaruh CAR, NPF, BOPO dan FDR terhadap Profitabilitas. Yogyakarta: Universitas Islam Negeri Sunan Kalijaga.

Hardiyanti. (2012). Pengaruh CAR, NPL dan LDR Terhadap ROA Pada Bank BUMN yang Go-Public. Makasar: Universitas Hasanudin.

Hendrayanti, S. (2013). Hendrayanti, Silvia.2013. Analisis Pengaruh Faktor Internal Dan Eksternal Terhadap Profitabilitas Perbankan. Diponegoro Journal Of Management, Vol. 2 No. 3, 1-15.

Khasanah, U. (2017). Pengaruh CAR, NPF, BOPO, FDR dan inflasi terhadap Return On Assets (ROA) pada Bank Umum Syariah Indonesia Periode 2012-2016. Salatiga: IAIN.

Kolapo, T. F. (2012). Credit risk and commercial bank performance in Nigeria: A panel model approach. Australian Journal of Business and Management Research, [3138].

Mahardian, P. (2008). Analisis Pengaruh Rasio CAR,BOPO, NPL, NIM dan LDR terhadap kinerja keuangan perbankan. Semarang: Universitas Diponegoro .

Mawardi, W. (2004). Analisis Faktor Faktor Yang Mempengaruhi Kinerja Keuangan Bank Umum Di Indonesia (Studi Kasus Pada Bank Umum dengan Total Asset Kurang Dari 1 Trilyun). Semarang: Universitas Diponegoro.

Mudrajad, K. (2002). Manajemen Perbankan: Teori dan Aplikasi. Yogyakarta: BPFE. Hlm. 462.

Muhammad. (2013). Akuntansi Syariah Teori dan Praktik untuk Perbankan Syariah. Edisi Pertama. Hlm 431. Yogyakarta: Sekolah Tinggi Ilmu Manajemen YKPN. .

Muliawati, M. K. (2015). Faktor-Faktor Penentu Profitabilitas Bank Syariah di Indonesia. . Management Analysis Journal. Vol. 4. No.1.

Pahlevie, H. N. (2009). Analisis Pengaruh CAR, NIM, LDR, NPL, BOPO dan EAQ Terhadap Perubahan Laba (Studi Empiris: Pada Bank Umum di Indonesia Periode 
Laporan Keuangan Tahun 2004-2007). Semarang: Universitas Diponegoro.

Ponttie, P. (2007). Analisis Pengaruh Rasio-rasio keuangan terhadap Kinerja Bank Umum di Indonesia (Studi Empiris Bank-bank Umum yang Beroperasi di Indonesia). Semarang: Universitas Diponegoro.

Pramudhito, S. R. (2014). Analisis Pengaruh CAR, NPF, BOPO, FDR dan NCOM terhadap Profitabilitas Bank Umum Syariah di Indonesia. Yogyakarta: STIE YKPN.

Pratiwi, L. P. (2015). Pratiwi, Luh Putu Sukma Wahyuni., dan Ni Luh Putu Wiagustini. 2015. Pengaruh CAR, BOPO, NPL Dan LDR Terhadap Profitabilitas. E-Jurnal Manajemen Unud Vol 5 No 4, 2137-2166.

Puspitasari, D. (2009). Analisis Pengaruh CAR, NPL, PDN, NIM, BOPO, LDR dan Suku Bunga SBI terhadap ROA. Semarang: Universitas Diponegoro.

Restiyana. (2011). Analisis Pengaruh CAR, NPL, BOPO, LDR, dan NIM Terhadap Profitabilitas Perbankan (Studi pada Bank Umum di Indonesia periode 20062010). . Semarang.: Universitas Diponegoro.

Rivai, V. A. (2010). Islamic Banking, Sistem Bank Islam Bukan Hanya Solusi Menghadapi Krisis Namun Solusi dalam Menghadapi Berbagai Persoalan Perbankan \& Ekonomi Global. Jakarta.: PT.Bumi Aksara.

Sangia, A. (2012). Analisis Pengaruh CAR, FDR, BOPO, dan NCOM terhadap Profitabilitas Bank Umum Syariah. Semarang: Universitas DIponegoro.

Sekaran, U. (2011). Research Methods For Business, Metodologi Penelitian Untuk Bisnis. Edisi 4. Jakarta: Salemba Empat.

Utami, S. R. ( 2015). Comparison Between Bank Performance Of Commercial Bank, State Owned Bank, And Foreign Owned Bank In Indonesia During The Period 20052009. International Journal of Advanced Research in Management and Social Sciences, 4(10), 37-54.

Warsa, N. M. (2016). Pengaruh CAR, LDR Dan NPL Terhadap ROA Pada Sektor Perbankan Di Bursa Efek Indonesia. . E-Jurnal Manajemen Unud, 5(5), 2842 2870.

Werdaningtyas. (2002). Faktor yang Mempengaruhi Profitabilitas Bank Take Over Pramerger di Indonesia. . Jurnal Manajemen Indonesia.

Wibowo, M. S. (2013). Analisis Pengaruh Suku Bunga, Inflasi, CAR, BOPO, NPF Terhadap Profitabilitas Bank Syariah. Diponegoro Journal Of Management Volume 2, Nomor 2. , 1-10.

Widowati, B. S. (2015). Pengaruh Rasio Keuangan Terhadap Profitabilitas Perbankan Di Indonesia. Jurnal Ilmu \& Riset Akuntansi, Vol. 4 No.6, Hal: 1-15.

Widyaningrum L, S. D. (2015). Pengaruh CAR, NPF, FDR dan OER terhadap ROA pada Bank Pembiayaan Rakyat Syariah di Indonesia. JESTT, 2 (12), 970-985.

Windriya, A. (2014). Analisis Pengaruh Faktor Eksternal Dan Faktor Internal terhadap Profitabilitas Bank Umum Syariah Indonesia 2008-2013. Semarang: Universitas Diponegoro. 